\title{
PENGEMBANGAN TRAINER SIGNAL CONDITIONING
}

\author{
Oleh \\ Djoko Santoso, Slamet, Pipit Utami, Bekti Wulandari \\ Jurusan Pendidikan Teknik Elektronika, Fakultas Teknik \\ Universitas Negeri Yogyakarta \\ djokosantoso@uny.ac.id
}

\begin{abstract}
ABSTRAK
Penelitian ini bertujuan untuk mengembangkan trainer signal conditioning dan menilai kelayakan trainer signal conditioning. Penelitian ini menggunakan model pengembangan yang terdiri dari analisis, desain, implementasi dan evaluasi, dimana letak evaluasi dan revisi terletak pada tiap tahapan. Evaluasi dilakukan oleh ahli materi, ahli media dan pengguna. Hasil penelitian menunjukkan bahwa pengembangan trainer signal conditioning melalui beberapa tahapan, diantaranya: (1) analisis diperoleh temuan bahwa: (a) alat dan pedoman praktik kurang update dan tidak match dengan dunia industri; (b) mahasiswa memerlukan gambaran hasil praktik; dan (c) mahasiswa memerlukan kemampuan trouble shooting; (2) pada tahapan desain diperoleh: (a) desain koper boks media yang didalamnya berisi 6 trainer yang terpasang dibagian atas koper, kemudian bagian dalam koper terdapat area signal conditioning, area project board, area alat ukur, area pembacaan signal menggunakan LCD, area penyimpan komponen dan area kabel; (b) pedoman praktik yang berisi 6 job praktik sesuai trainer yang dikembangkan; dan (c) manual book berisi petunjuk penggunaan trainer; (3) pada tahapan implementasi dilakukan pembuatan media berdasarkan desain; (4) pada tahapan evaluasi dilakukan penilaian media, dimana revisi dilakukan pada tiap tahapan. Hasil penelitian berikutnya menunjukkan bahwa nilai kelayakan media trainer signal conditioning secara umum memperoleh nilai 3,28 yang diintrepetasikan dalam kategori Sangat Baik dan diperoleh beberapa masukan yang telah diperbaiki, terkait penambahan jumlah bahan praktikum, penggantian kabel yang putus dan pembuatan kalimat instruksi. Nilai kelayakan yang dapat diinterpetasikan sangat baik pada trainer signal conditioning menunjukkan bahwa trainer ini dapat digunakan dalam pembelajaran dikelas.
\end{abstract}

Kata Kunci : pengembangan, trainer, signal conditioning, kelayakan

\section{PENDAHULUAN}

Teknologi instrumentasi mengalami perkembangan yang pesat dengan demikian dibutuhkan sumber daya manusia (SDM) yang berkompeten dan "melek" instrumentasi. Jurusan Pendidikan Teknik Elektronika sebagai salah satu lembaga pendidikan yang bertujuan menghasilkan lulusan dengan kemampuan elektronika yang kompeten salah satunya bidang instrumentasi memiliki tanggungjawab dalam penyiapan SDM tersebut. Peran yang bisa dilakukan pihak Jurusan salah satunya adalah peningkatan kualitas pembelajaran melalui pengunaan trainer pembelajaran.

Dibutuhkan trainer pembelajaran yang mampu meningkatkan kualitas pembelajaran pada mata kuliah instrumentasi. Hal tersebut sejalan dengan temuan yang ada, dimana kondisi trainer kit yang ada dan masih digunakan dalam perkuliahan mata kuliah Instrumentasi sudah dalam kondisi yang kurang bagus karena faktor usia. Belum ada pembaruan dan maintenance yang dilakukan secara nyata belum dapat 
memaksimalkan kinerjanya terkait faktor usia penggunaan trainer kit. Selain itu trainer yang ada belum menyesuaikan dengan perkembangan teknologi instrumentasi yang sedang berkembang saat ini (belum match). Untuk mendukung tercapainya pemahaman mengenai materi tersebut dibutuhkan modul praktek. Modul praktek yang dimaksud berupa trainer yang terdiri dari perangkat hardware dan pedoman praktek berupa buku teks yang secara garis besar berisi uraian materi, langkah praktek dan penugasan. Trainer tersebut dapat digunakan oleh mahasiswa untuk membuktikan teori yang dipelajari pada mata kuliah Instrumentasi. Dengan demikian tepat apabila dalam penelitian ini akan dikembangkan trainer sekaligus pedoman praktek dalam mata kuliah Instrumentasi. Salah satu materi yang penting dalam mata kuliah Instrumentasi adalah Signal Conditioning. Semua perangkat instrumentasi membutuhkan signal conditioning didalamnya. Dengan demikian trainer yang akan dikembangkan dalam penelitian ini dibatasi dalam materi signal conditioning.

Pembelajaran adalah serangkaian aktivitas yang sengaja diciptakan dengan maksud untuk memudahkan terjadinya proses belajar pada siswa untuk mencapai tujuan belajar yaitu siswa mampu mewujudkan atau paling tidak mendekati praktik pembelajaran yang ideal. (Gagne, Briggs \& Wager (Winataputra, 2008: 19); Trianto (2009: 17); Hariyanto dan Suyono (2011: 209)). Dengan demikian pada mata kuliah Praktik Instrumentasi diperlukan media pembelajaran. Heinich et.al. (2005: 7), "Instruction is the arrangement of information and environment to facilitate learning." Lingkungan berupa model, metode, strategi, media, dan atau sarana yang dibutuhkan untuk memfasilitasi belajar siswa. Berdasarkan uraian di atas, dapat disimpulkan bahwa pembelajaran merupakan kegiatan yang disengaja dalam menyampaikan informasi yang diciptakan untuk memfasilitasi pencapaian tujuan yang diharapkan dan memperoleh perubahan tingkah laku pada peserta didik secara keseluruhan.

Dalam kegiatan pembelajaran, tujuan yang dicapai bersifat behavioral atau berbentuk tingkah laku yang dapat diamati dan diukur, yang kesemuanya itu harus dicapai dengan suatu strategi di mana kegiatan pembelajaran dilaksanakan dengan kondisi yang diciptakan secara sistematis, seperti mengintegrasikan komponen metode, sarana prasarana, media, dan lainnya, sehingga peserta didik (mahasiswa) mudah dalam mencapai tujuan pembelajaran yang telah ditetapkan. Dalam pencapaian tujuan pembelajaran tersebut, sangat diperlukan keefektifan pengajaran baik secara materi maupun strategi. Namun dalam praktik di lapangan, berbagai permasalahan sebagai penghambat pencapaian tujuan pembelajaran tersebut selalu bermunculan, bisa berasal dari faktor pengajar, sarana prasana maupun peserta didik itu sendiri. Salah satu upaya 
yang dapat dilakukan untuk meminimalisirkan permasalahan-permasalahan tersebut adalah dengan melakukan pengembangan media pembelajaran. Berdasarkan gambar di bawah menunjukkan bahwa komponen bahan (media) merupakan salah satu jenis sumber belajar yang berfungsi menyelesaikan permasalahan dalam suatu proses pembelajaran. Keefektifan media pembelajaran memegang andil besar dalam keefektifan pengajaran. Semakin baik kualitas media pembelajaran, maka semakin efektif pengajaran dan secara tidak langsung tujuan pembelajaran akan lebih mudah dan cepat tercapai.

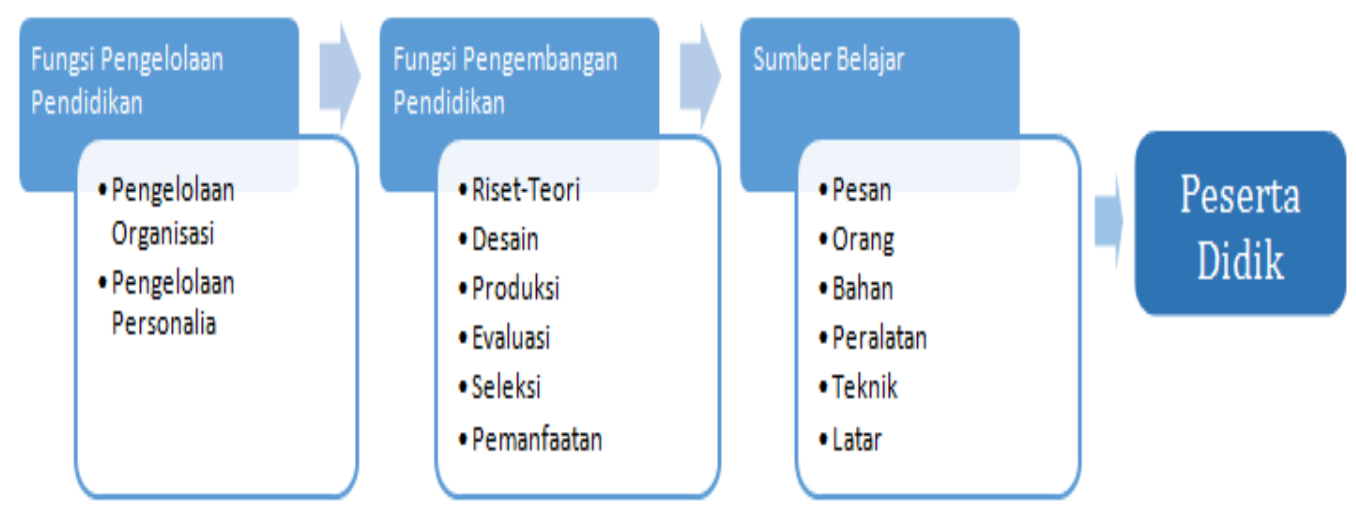

Gambar 1. Bagan Kawasan Teknologi Pendidikan (Soeharto, Karti : 1996)

Media pembelajaran adalah sesuatu yang digunakan untuk menyampaikan informasi agar dapat merangsang pikiran, perhatian, dan motivasi siswa dalam mengikuti pelajaran yang bisa digunakan didalam atau diluar kelas secara individual atau kelompok dalam bentuk hardware atau software, visual dan atau audio (Miarso, (2009: 458); Sadiman, (2009:7); dan Arsyad (2007: 6-7)). Perkuliahan praktek instrumentasi menerapkan pembelajaran berbasis kompetensi. Didalam pembelajaran praktek, hal yang diharapkan dicapai adalah kompetensi mahasiswa setelah mengikuti pembelajaran. Beberapa karakteristik pembelajaran berbasis kompetensi adalah penyampaian dalam pembelajaran menggunakan pendekatan dan metode yang bervariasi serta sumber belajar bukan hanya guru, tetapi juga sumber belajar lainnya yang memenuhi unsur edukatif (Mulyasa, 2006:42). Dari beberapa karakteristik tersebut, peran modul praktek dalam pembelajaran praktek memiliki arti yang tidak kalah besar dengan dosen.

Bertolak dari paparan diatas peneliti sebagai dosen jurusan Pendidikan Teknik Elektronika UNY memiliki tanggungjawab dan kepedulian untuk mengembangkan modul praktek instrumentasi yang akurat, mengikuti perkembangan teknologi serta yang dapat meningkatkan kualitas pembelajaran pada mata kuliah Instrumentasi. 


\section{METODE}

Penelitian ini menggunakan model pengembangan yang terdiri dari analisis, desain, implementasi dan evaluasi, dimana letak evaluasi dan revisi terletak pada tiap tahapan (Lee \& Owens (2004); Soulier (1988); Hannafin \& Pack (1988); Borg \& Gall (1987); Alessi \& Trollip (2001:13)). Terkait pengembangan media pembelajaran, perlu dikaji pula mengenai kriteria media pembelajarn yang baik agar media dapat bermanfaat sesuai tujuan. Terdapat beberapa kriteria yang perlu diperhatikan dalam menentukan jenis media pembelajaran yang akan digunakan sehingga dapat memberikan kontribusi terhadap proses pembelajaran yang efektif dan efisien. Nana \& Ahmad (1991: 5-6) mengemukakan bahwa ada beberapa kriteria yang sebaiknya diperhatikan dalam pemilihan media, yaitu: (1) ketepatan dengan tujuan pembelajaran; (2) dukungan terhadap isi bahan pembelajaran; (3) kemudahan memperoleh media; (4) keterampilan guru dalam menggunakan; dan (5) sesuai dengan tingkat berfikir siswa.

Bentuk media pembelajaran juga perlu diperhatikan dalam menentukan bentuk yang paling tepat dikembangkan. Ada tiga kategori utama bentuk media pembelajaran menurut Arif (2011: 19), yaitu: (1) media penyaji yang mampu menyajikan informasi dengan muatan grafis, bahan cetak, gambar diam, media proyeksi diam, media audio diam, audio ditambah media visual diam, gambar hidup (film), televisi, dan multimedia; (2) media objek meliputi dua kelompok yaitu objek yang sebenarnya dan objek pengganti tiga dimensi yang mengandung informasi tidak dalam bentuk penyajian tetapi melalui ciri fisiknya seperti ukurannya, beratnya, bentuknya, susunannya, warnanya, fusngsinya, dan sebagainya; dan (3) media interaktif yang lebih menekankan pada perhatian siswa tidak hanya pada penyajian atau objek, tetapi dipaksa berinteraksi selama mengikuti pelajaran.

Dari paparan diatas, maka penggunaan modul praktek pada perkuliahan praktek instrumentasi dinilai sesuai dengan karakteristik pembelajaran berbasis kompetensi. Modul praktek tersebut disajikan dalam bentuk media penyaji berupa pedoman praktik dan media objek dalam bentuk trainer. Penggunaan modul praktek dalam proses perkuliahan praktek diperlukan agar terwujud pembelajaran (perkuliahan) praktek yang berkualitas dan bermakna bagi mahasiswa (kompetensi mahasiswa tercapai).

Media pembelajaran perlu dilakukan evaluasi agar dapat dinilai kelayakan dan kebermanfaatannya. Menurut Romi (2006: 20-22) terdapat tiga aspek dan kriteria penilaian dalam pembuatan media pembelajaran yaitu aspek perangkat lunak, aspek desain pembelajaran dan aspek komunikasi visual. Dalam penelitian media yang dikembangkan media interaktif dengan perangkat lunak sebagai bagian utama dari user 
interface. Dari ketiga aspek tersebut, peneliti lebih memperhatikan aspek umum yaitu aspek desain pembelajaran terdiri dari: (a) kejelasan tujuan pembelajaran (rumusan, realitistis), (b) relevansi tujuan pembelajaran dengan SK/KD/Kurikulum, (c) cakupan dan kedalaman tujuan pembelajaran, (d) ketepatan penggunaan strategi pembelajaran, (e) interaktivitas, (f) pemberian motivasi belajar, (g) kontekstualitas dan aktualitas kelengkapan dan kualitas bahan bantuan belajar, (h) kesesuaian materi dengan tujuan pembelajaran, (i) kedalaman materi, (j) kemudahan untuk dipahami, (k) sistematis, runut, alur logika jelas, (l) kejelasan uraian, pembahasan, contoh simulasi, latihan, (m) konsistensi evaluasi dengan tujuan pembelajaran, (n) ketepatan dan ketetapan alat evaluasi, dan (o) pemberian umpan balik terhadap hasil evaluasi. Selain itu menurut Walker \& Hess (dalam Cecep \& Bambang, 2011: 145) terdapat kriteria penilaian media pembelajaran berdasarkan pada kualitas, yaitu: (1) kualitas isi dan tujuan (ketepatan, kepentingan, kelengkapan, keseimbangan, minat atau perhatian, keadilan dan kesesuaian dengan situasi siswa); (2) kualitas instruksional (memberikan kesempatan belajar, memberikan bantuan untuk belajar, kualitas memotivasi, fleksibilitas pembelajarannya, hubungan dengan program pembelajaran lainnya, kualitas sosial interaksi pembelajarannya, kualitas tes dan penilaiannya, dapat memberi dampak bagi siswa, dapat membawa dampak bagi guru dan pembelajarannya); dan kualitas teknis (keterbacaan, mudah digunakan, kualitas tampilan atau tayangan, kualitas penanganan jawaban, kualitas pengelolaan programnya, kualitas pendokumentasiannya).

Dengan memperhatikan jenis media, mengadaptasi kriteria penilaian media pembelajaran dan memperhatikan kebutuhan penilaian masing-masing validator, maka diperoleh indikator yang digunakan dalam penilaian ini mencakup aspek-aspek di atas. Namun, ada beberapa indikator yang tidak digunakan karena menyesuaikan kebutuhan pengembangan penelitian yang dikembangkan untuk media signal conditioning (trainer dan pedoman praktik). Indikator yang digunakan dalam penelitian ini meliputi tiga aspek yaitu aspek edukatif (materi), teknis dan estetika (tampilan). Evaluasi media dalam penelitian ini dilakukan oleh tiga kelompok secara umum, yaitu ahli materi, ahli media dan pengguna. Masing-masing aspek evaluasi media disesuaiakan sesuai kebutuhan penilaian oleh tiap validator. Aspek penilaian yang dinilai ahli materi adalah aspek materi yang terdiri dari kesesuaian, kelengkapan, meningkatkan pemahaman, memberikan kesempatan belajar dan kesesuaian dengan daya pikir siswa. Aspek yang dinilai oleh ahli media terdiri dari aspek teknis (kualitas alat, luwes atau fleksibel, keamanan dan kemanfaatan) dan aspek tampilan (bentuk yang estetis, keserasian, keterbacaan dan kerapian). Aspek yang dinilai oleh pengguna adalah aspek materi 
(kesesuaian, kelengkapan, dan memberikan kesempatan belajar), aspek teknis (luwes atau fleksibel, keamanan, dan kemanfaatan) dan aspek tampilan (bentuk yang estetis, keserasian, keterbacaan dan kerapian). Berikut ini adalah kisi-kisi instrumen kelayakan yang digunakan untuk menilai trainer signal conditioning dalam penelitian ini.

Tabel 1. Kisi-kisi Instrumen untuk Ahli Materi, Ahli Media dan Mahasiswa

\begin{tabular}{|c|c|c|}
\hline Ahli & Aspek & Indikator \\
\hline \multirow[t]{5}{*}{ Materi } & \multirow{5}{*}{$\begin{array}{l}\text { Edukatif } \\
\text { (Materi) }\end{array}$} & Kesesuaian \\
\hline & & Kelengkapan \\
\hline & & Meningkatkan pemahaman \\
\hline & & Memberikan kesempatan belajar \\
\hline & & Kesesuaian dengan daya pikir siswa \\
\hline \multirow[t]{8}{*}{ Media } & \multirow{4}{*}{ Teknis } & Kualitas alat \\
\hline & & Luwes atau fleksibel \\
\hline & & Keamanan \\
\hline & & Kemanfaatan \\
\hline & \multirow{4}{*}{$\begin{array}{l}\text { Estetika } \\
\text { (Tampilan) }\end{array}$} & Bentuk yang estetis \\
\hline & & Keserasian \\
\hline & & Keterbacaan \\
\hline & & Kerapian \\
\hline \multirow[t]{10}{*}{ Mahasiswa } & \multirow{3}{*}{$\begin{array}{l}\text { Edukatif } \\
\text { (Materi) }\end{array}$} & Kesesuaian \\
\hline & & Kelengkapan \\
\hline & & Memberikan kesempatan belajar \\
\hline & \multirow{3}{*}{ Teknis } & Luwes atau fleksibel \\
\hline & & Keamanan \\
\hline & & Kemanfaatan \\
\hline & \multirow{4}{*}{$\begin{array}{l}\text { Estetika } \\
\text { (Tampilan) }\end{array}$} & Bentuk yang estetis \\
\hline & & Keserasian \\
\hline & & Keterbacaan \\
\hline & & Kerapian \\
\hline
\end{tabular}

Analisis data yang dipakai dalam rangka menjawab rumusan masalah pada penelitian menggunakan teknis analisis deskriptif kuantitatif dan evaluatif. Teknik ini digunakan karena dalam penelitain R\&D tidak melakukan uji hipotesis. Pada penelitian ini dilakukan pengujian kelayakan produk hardware yang digunakan dalam mata kuliah Instrumentasi di Prodi Teknik Elektronika. Teknis analisis deskriptif dilakukan untuk menentukan kelayakan media dalam fungsinya. Dalam kuisioner diberikan empat alternatif pilihan untuk memberikan tanggapan tentang media yang dikembangkan, yaitu; sangat baik dengan skor 4, baik dengan skor 3, kurang baik dengan skor 2, dan sangat kurang baik dengan skor 1 . Skor yang diperoleh kemudian dikonversikan menjadi nilai, pada skala 4. Berikut ini adalah tabel konversi nilai skala 4. 
Tabel 2. Konversi Data Kualitatif Menjadi Data Kuantitatif (Skala 4)

\begin{tabular}{|c|l|l|l|}
\hline Skala & \multirow{2}{*}{ Kriteria } & \multicolumn{2}{|c|}{ Skor } \\
\cline { 3 - 4 } & & \multicolumn{1}{|c|}{ Perhitungan } & \multicolumn{1}{|c|}{ Hasil } \\
\hline 4 & Sangat Baik & $2,5+(1,5 \times 0,5)$ s.d. $2,5+(3 \times 0,5)$ & 3,25 s.d. 4 \\
\hline 3 & Baik & $2,5+(0 \times 0,5)$ s.d. $2,5+(1,5 \times 0,5)$ & 2,5 s.d. 3,25 \\
\hline 2 & Kurang & $2,5-(1,5 \times 0,5)$ s.d. $2,5+(0 \times 0,5)$ & 1,75 s.d. 2,5 \\
\hline 1 & Sangat Kurang & $2,5-(3 \times 0,5)$ s.d. $2,5-(1,5 \times 0,5)$ & 1 s.d. 1,75 \\
\hline
\end{tabular}

Untuk mencari skor rata-rata dalam memberikan penilaian terhadap produk yang telah dikembangkan, maka digunakan rumus;

$$
\begin{aligned}
& \mathrm{X}_{\mathrm{i}}=\frac{\sum \mathrm{x}}{\sum \mathrm{ax} \sum \mathrm{n}} \\
& \text { keterangan : } \\
\mathrm{Xi} & =\text { skor rata-rata } \\
\sum \mathrm{x} & =\text { jumlah skor } \\
\sum \mathrm{a} & =\text { jumlah aspek yang diamati } \\
\mathrm{n} \quad & =\text { jumlah responden }
\end{aligned}
$$

\section{HASIL DAN PEMBAHASAN}

Hasil temuan pada tahapan analisis berupa kurang mutakhirnya alat dan pedoman praktik menunjukkan bahwa peralatan di dunia industri dan di kelas tidak match. Hal tersebut membuat pembelajaran di kelas tidak dapat memberikan pengalaman nyata sebagaimana yang terjadi di dunia industri. Oleh karena itu LPTK sebagai lembaga pembelajaran vokasi tidak dapat berfungsi dengan baik. Sebagaimana prinsip yang disampaikan oleh Prosser (1949), yaitu "Vocational education will be efficient in proportion as the environment in which the learner is trained is a replica of the environment in which he must subsequently work" dan "Training meets the market demands for labor whatever these may be in any given occupation". Dimana agar pembelajaran vokasi efisien perlu adanya replika lingkungan dunia industri di kelas dan pendidikan kejuruan harus memperhatikan permintaan pasar, dalam hal ini misalnya dalam bentuk replika media pembelajaran yang sesuai kebutuhan pemakaian di dunia industri.

Temuan lain dalam tahap analisis adalah mahasiswa memerlukan gambaran hasil praktik. Dengan kata lain perlu adanya pembanding antara nilai/hasil yang diharapkan dengan hasil yang diperoleh oleh mahasiswa saat praktik. Dengan melakukan 
pembandingan maka mahasiswa akan memahami apakah rangkaian yang dirakit telah sesuai atau belum. Hal tersebut sejalan dengan yang disampaikan Anderson \& Krathwohl (2001:70-76), bahwa salah satu ndikator pemahaman adalah comparing (membandingkan).

Temuan ketiga adalah mahasiswa perlu memiliki kemampuan trouble shooting, hal ini terkait penggunaan project board dalam kegiatan praktikum. Mahasiswa sering mendapatkan permasalahan saat merangkai rangkaian dengan project board. Dilain pihak pencapaian tujuan praktikum harus melalui tahapan merangkai rangkaian yang berhasil. Dengan demikian temuan tersebut sejalan dengan apa yang disampaikan Santrock (2011: 316) bahwa "problem solving involves finding an appropriate way to attain a goal", sehingga tepat bahwa praktikum mahasiswa tetap melibatkan project board untuk melatih kemampuan trouble shooting.

Analisis dan dukungan teori tersebut dilanjutkan pada tahap desain. Pada tahapan desain diperoleh: (1) desain koper boks media yang didalamnya berisi 6 trainer yang terpasang dibagian atas koper, kemudian bagian dalam koper terdapat area signal conditioning, area project board, area alat ukur, area pembacaan signal menggunakan LCD, area penyimpan komponen dan area kabel; (2) pedoman praktik yang berisi 6 job praktik sesuai trainer yang dikembangkan; dan (3) manual book berisi petunjuk penggunaan trainer. Pada tahapan implementasi dilakukan pembuatan media berdasarkan desain. Tujuan media pembelajaran adalah Pengembangan media signal conditioning yang memberikan gambaran hasil praktikum dan memiliki titik-titik pengukuran) dan tetap mengembangkan kemampuan trouble shooting (terdapat project board). Terdapat trainer yang dikembangkan, yaitu penguat beda, penguat instrumentasi, filter, konverter ADC, konverter DAC dan penghitung denyut nadi. Setelah trainer dikembangkan, selanjutnya disusun pedoman praktik dan manual book penggunaan trainer. Pada tahapan evaluasi dilakukan penilaian media. Evaluasi dilakukan di setiap tahapan baik sebelum uji kelayakan maupun setelah uji kelayakan. Hal tersebut sesuai seperti yang disampaikan sesuai model Hannafin \& Pack (1988) yang menyatakan bahwa letak evaluasi dan revisi pada terletak pada tiap fase.

Sebelum dilakukan uji kelayakan pada tahap evaluasi baik uji alfa maupun uji beta, peneliti melakukan uji kinerja untuk memastikan kesesuaian media yang dikembangkan sesuai dengan target yang diharapkan. Hal tersebut sesuai dengan Allessi dan Pressman (2010:530) yang menyatakan bahwa pengujian fokus pada kinerja sistem secara komprehensif. Uji kinerja telah menunjukkan hasil sesuai target, dimana semuai komponen dapat berfungsi dengan baik dan nilai yang ditunjukkan pada titik-titik 
pengukuran menunjukkan nilai yang sesuai. Dengan demikian dilakukan pengujian selanjutnya yaitu uji ahli materi, uji ahli media, uji 3 pengguna terbatas dan uji lapangan terhadap 20 pengguna. Berikut ini adalah ringkasan dari uji alfa dan uji beta.

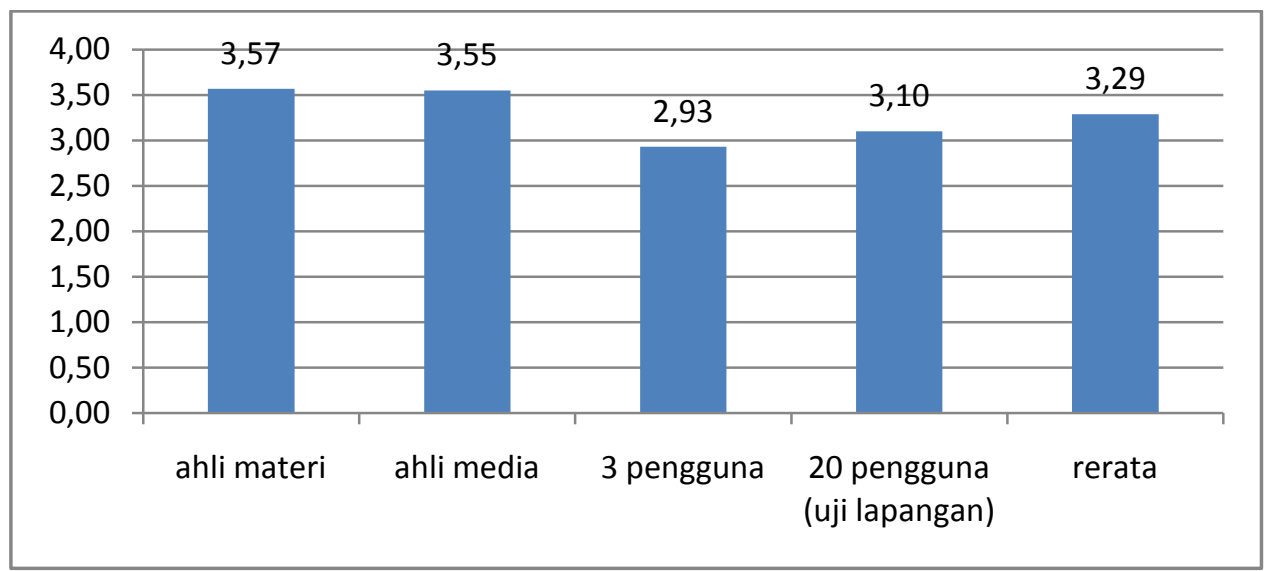

Gambar 10. Diagram batang hasil uji lapangan per butir pernyataan

Perbaikan dari saran ahli materi dan ahli media adalah penambahan jumlah opamp sesuai kebutuhan, penggantian kabel yang putus dan pembuatan kalimat instruksi. Ketercukupan jumlah bahan praktikum menunjang keberhasilan praktikum, oleh karena itu saran tersebut diupayakan. Meskipun terdapat revisi berdasarkan masukan ahli materi dan media, akan tetapi penilaian menunjukkan hasil Sangat Baik bernilai 3,57 dari ahli materi dan hasil Sangat Baik bernilai 3,55 dari ahli media. Perbaikan dari saran pengguna terbatas dan pengguna lapangan adalah diketahuinya adanya keterbatasan dalam pemenuhan kelengkapan materi dari pengguna seperti dalam bentuk modul. Hal tersebut belum dikembangkan dalam penelitian ini karena pada analisis kebutuhan yang dikembangkan adalah pedoman praktik dimana berisi kajian teori secara singkat. Kajian teori singkat tersebut secara materi telah dinilai sesuai oleh ahli materi sehingga tetap dapat dilanjutkan. Temuan lainnya adalah adanya keluhan dari para pengguna terkait dimensi yang terlalu besar yang berdampak pada trainer yang berat, sehingga menyulitkan untuk pembelajaran mandiri karena susah untuk dimobilisasi. Hal tersebut menjadi keterbatasan dalam penelitian ini dan menjadi masukan untuk penelitian selanjutnya terkait trainer. Keterbatasan tersebut terkait desain awal yang dilakukan, berdasarkan besarnya rangkaian yang disesuaikan dengan kemudahan pengguna dalam membaca rangkaian dan melakukan pengukuran di titik-titik pengukuran. Temuan lain adalah belum adanya penugasan yang merangsang kreatifitas dan upaya memecahkan permasalahan, pedoman praktek berisi langkah per langkah praktikum yang urut dan 
berpatokan pada pengukuran di titik-titik pengukuran yang dinilai belum dapat meningkatkan kreatifitas pengguna dalam memecahkan permasalahan. Temuan ini di tindaklanjuti dengan memberikan tambahan penugasan yang bersifat aplikatif untuk dikerjakan oleh pengguna. Meskipun beberapa masukan dari pengguna merupakan hal yang masih menjadi keterbatasan dari media ini, akan tetapi dari penilaian pada pengguna tersebut diperoleh nilai 2,93 (uji terbatas) dan 3,10 (uji lapangan) yang termasuk dalam kategori Baik.

\section{SIMPULAN}

Hasil penelitian menunjukkan bahwa pengembangan trainer signal conditioning melalui beberapa tahapan, diantaranya: (1) analisis diperoleh temuan bahwa: (a) alat dan pedoman praktik kurang update dan tidak match dengan dunia industri; (b) mahasiswa memerlukan gambaran hasil praktik; dan (c) mahasiswa memerlukan kemampuan trouble shooting; (2) pada tahapan desain diperoleh: (a) desain koper boks media yang didalamnya berisi 6 trainer yang terpasang dibagian atas koper, kemudian bagian dalam koper terdapat area signal conditioning, area project board, area alat ukur, area pembacaan signal menggunakan LCD, area penyimpan komponen dan area kabel; (b) pedoman praktik yang berisi 6 job praktik sesuai trainer yang dikembangkan; dan (c) manual book berisi petunjuk penggunaan trainer; (3) pada tahapan implementasi dilakukan pembuatan media berdasarkan desain; (4) pada tahapan evaluasi dilakukan penilaian media, dimana revisi dilakukan pada tiap tahapan.

Hasil penelitian berikutnya menunjukkan bahwa nilai kelayakan media trainer signal conditioning secara umum memperoleh nilai 3,28 yang diintrepetasikan dalam kategori Sangat Baik dan diperoleh beberapa masukan yang telah diperbaiki, terkait penambahan jumlah bahan praktikum, penggantian kabel yang putus dan pembuatan kalimat instruksi. Nilai kelayakan yang dapat diintrepetasikan sangat baik pada trainer signal conditioning menunjukkan bahwa trainer ini dapat digunakan dalam pembelajaran dikelas. 


\section{DAFTAR PUSTAKA}

Alessi, S. M. \& Trollip, S. R. (2001). Multimedia for learning: Methods and development $3^{\text {rd }}$ ed. Massachusetts: Allyn and Bacon.

Arsyad, A. (2007). Media Pembelajaran. Jakarta: PT Raja Grafindo Persada.

Hamalik, Oemar. (2010). Perencanaan pengajaran berdasarkan pendekatan sistem. Jakarta: Bumi Aksara

Hannafin, M. J. \& Peck, K. L. (1988). The design, development, and evaluation of instruction software. New York: MacMiillan Publishing Company.

Heinich, R., Molenda, M., Russel, J.D., et al. (2005). Instructional media and technologies for learning $\left(8^{\text {th }} e d\right)$. New Jersey: Prentice Hall.

Lee, W. \& Owens, D. L. (2004). Multimedia based instructional design: Computer based training web based training distance broadcast training, performance based solutions $2^{\text {nd }} e d$. San Fransisco: Pfeiffer.

Made Wena. (2010). Strategi pembelajaran inovatif kontemporer suatu tinjauan konseptual operasional. Jakarta: Bumi Aksara

Miarso, Y. (2009). Menyemai Benih Teknologi Pendidikan. Jakarta: Kencana Prenada Media group atas kerjasama Pustekkom-DIKNAS.

Mulyasa, E. (2006). KURIKULUM BERBASIS KOMPETENSI Konsep, Karakteristik, Implementasi dan Inovasi. Bandung: PT Remaja Rosdakarya Offset

Sadiman, A. S. (2009). Media Pendidikan : Pengertian, Pengembangan dan Pemanfaatannya. Jakarta: PT RajaGrafindo Persada.

Santrock, J. W. (2011). Educational psychology. ( $5^{\text {th }}$ ed.). New York: McGraw Hill.

Slameto. (1995). Belajar dan faktor-faktor yang mempengaruhinya. Jakarta: PT Rineka Cipta.

Soehartoo Karti dan Mustaji. (1996). Dasar-dasar Media Pembelajaran. Surabaya : Unniversity Press IKIP Surabaya.

Sukardjo. (2005). Desain pembelajaran: Evaluasi pembelajaran. Handout perkuliahan: Program Pascasarjana Universitas Negeri Yogyakarta.

Suyono \& Hariyanto. (2011). Belajar dan pembelajaran. Bandung: PT. Remaja Rosdakarya.

Pengembangan Trainer Signal Conditioning....(Djoko Santoso, Slamet, Pipit Utami, Bekti Wulandari) 
Winataputra, U. S., et al. (2008). Teori belajar dan pembelajaran. Jakarta: Penerbit Universitas Terbuka.

Prosser, Charlies. (1994). Prosser's Sixteen Theorems on Vocational Education: A Basis for Vocational Philosophy. Versi elektronik diambil dari: http://www.morgancc.edu/docs/io/Glossary/Content/PROSSER.PDF 